\title{
Molecular diagnosis of human papillomavirus in the development of cervical cancer
}

\author{
Lourdes Gutiérrez-Xicoténcatl, Dra en C, (I) Tanya Plett-Torres, M en C,(I) \\ Claudia L Madrid-González, MC,(I) Vicente Madrid-Marina, Dr en C.(2)
}

\author{
Gutiérrez-Xicoténcatl L, Plett-Torres T, \\ Madrid-González CL, Madrid-Marina V. \\ Molecular diagnosis of human papillomavirus \\ in the development of cervical cancer. \\ Salud Publica Mex 2009;5I suppl 3:S479-S488.
}

\begin{abstract}
Cervical cancer (CC) is a major public health problem in developing countries and its most significant etiological risk factor is infection by the human papillomavirus (HPV). The main approach to date for the prevention of CC has been through screening programs, using the cervical smear (PAP test) to detect precursory lesions. The sensitivity and specificity of the PAP smear depend on the skills of the observer to recognize and classify a variety of cellular abnormalities. The development of early diagnoses to detect HPV infection has been a problem as cytology and colposcopy identify the lesion at an advanced stage.Therefore, molecular approaches have become more successful for early CC diagnosis. These molecular techniques recognize HPV DNA sequences by DNA hybridization, PCR-RFLP, hybrid capture and reverse line blot systems. Unfortunately, these systems cannot determine whether the HPV infection is active, latent or persistent.Thus, immunological techniques such as Western blot and ELISA have been designed to follow the immune response against the virus, and they can also be used to identify the stage of the infection. Several companies have developed, manufactured and merchandised gene-based testing systems for the screening, monitoring and diagnosis of HPV. Our review and comments focus on the critical analysis of existing products and their use in clinical practice as well as on immunological systems used mainly in research, but that may be applied in large population screening programs.
\end{abstract}

Gutiérrez-Xicoténcatl L, Plett-Torres T, Madrid-González CL, Madrid-Marina V.

Diagnóstico molecular del virus del papiloma humano en el desarrollo del cáncer cervical.

Salud Publica Mex 2009;5I supl 3:S479-S488.

\section{Resumen}

El cáncer cervical (CC) es el mayor problema de salud pública en países en vías de desarrollo, al ser la infección por el virus del papiloma humano (HPV) el factor etiológico más importante de esta enfermedad. Actualmente, el principal acercamiento para la prevención del $\mathrm{CC}$ ha sido a través de programas de detección oportuna del cáncer, lo cual se ha realizado a través del estudio citológico del Papanicolaou (Pap) para la detección de lesiones precursoras. Sin embargo, la sensibilidad y especificidad de la prueba de Pap depende de la destreza del observador en el reconocimiento y clasificación de diferentes anormalidades en las células. El desarrollo de sistemas de diagnóstico temprano para la detección de la infección por HPV ha sido problemático debido a que tanto la citología como la colposcopía identifican la lesión cervical en estadios muy avanzados. De esta forma, la aplicación de las pruebas moleculares ha sido exitosa en el diagnóstico temprano del CC. Estas técnicas moleculares se basan en el reconocimiento de secuencias de ADN de HPV por medio de hibridación del ADN, PCR-RFLP, captura de híbridos (hybrid capture) y el sistema de línea reversa (reverse line blot). Desafortunadamente, estos sistemas no pueden identificar si se trata de una infección activa, latente o persistente. Por esta razón, las técnicas inmunológicas como elWestern blot y el ELISA han sido diseñadas para realizar el seguimiento de la respuesta inmune contra el virus. Por ello, aquí se hace una revisión de las técnicas moleculares utilizadas para de-

(I) Departamento de Interacción Epidemiológica, Centro de Investigación sobre Enfermedades Infecciosas, Instituto Nacional de Salud Pública. Cuernavaca, Morelos, México.

(2) Dirección de Infecciones Crónicas y Cáncer, Centro de Investigación sobre Enfermedades Infecciosas, Instituto Nacional de Salud Pública. Cuernavaca, Morelos, México. 
Key words: human papillomavirus; uterine cerival neoplasms; diagnosis tectar el HPV, como factor de riesgo del CC, así como las técnicas inmunológicas desarrolladas para el seguimiento de la respuesta inmune contra este virus. Existen diferentes compañías que han desarrollado, manufacturado y comercializado pruebas diagnósticas basadas en identificación de genes para el tamizaje, monitoreo y diagnóstico de HPV. Nuestra revisión se enfoca en el análisis de productos que existen en el mercado, así como en los sistemas inmunológicos usados en investigación y en programas de tamizaje de extensas poblaciones.

Palabras clave: virus del papiloma humano; neoplasias del cuello uterino; diagnóstico
$\mathrm{C}$ ervical cancer (CC) is one of the main public health problems worldwide, and it accounts for 231000 deaths each year. ${ }^{1,2}$ More than $80 \%$ of the 500000 new cases of CC are diagnosed in developing countries, and Latin America is the region with the highest incidence rates in the world. ${ }^{3,4}$ In Mexico, CC is one of the major causes of mortality among young women 35 to 59 years of age, and it accounts for around 5000 deaths every year. ${ }^{5}$ The introduction of effective population-based screening programs using the Papanicolaou test (Pap) to detect precancerous lesions has significantly reduced the number of CC cases in developed countries, but this has not been the case in developing countries. Despite the existence of a national screening program since 1974 , it is estimated that only $13 \%$ of the CC cases are detected in Mexico and this is due to the quality of the diagnostic system. In fact, mortality rates attributed to $\mathrm{CC}$ in Mexico have remained stable during the last three decades, at around 17 deaths per 100000 women. ${ }^{6,7}$

The viral origin of cervical cancer has now been proven beyond any reasonable doubt..$^{8,9}$ Recent studies have shown that HPV DNA can be found in $99.7 \%$ of all cervical carcinomas and types 16, 18, 31 and 45 are those most frequently found. ${ }^{8,10}$ Based on these observations, anogenital HPVs have been divided into two groups: the first is associated with a high risk (HR) of cervical cancer development -the HR-HPVs $(16,18,26,31,33,35,39,45,51,52,53,56,58,59,66,68,73$ and 82 ) - and the second with low carcinogenic potential -the low risk (LR) HPVs $(6,11,40,42,43,44,54,61,72$ and 81). ${ }^{10}$ It has now been proven that infection with an HR$\mathrm{HPV}$ is a necessary prerequisite for the development of $\mathrm{CC}$, and this is why the World Health Organization (WHO) has recognized HPV-16 and HPV-18 as carcinogenic agents for humans.

It is very well known that the role the HPV infection plays in the development of CC generates a humoral immune response against various viral antigens, but especially against the L1 major capsid protein. ${ }^{11}$ However, many of the techniques used to diagnose other viral infections have not been successful in the diagnosis of HPV infections due to the fact that it has not been possible to grow this virus in cell culture. Only recently have the HPV particles been propagated in vitro in raft cultures and xenografts, ${ }^{12}$ but the amount of viral particles obtained is very low to generate enough protein burdens to be used in immunological tests. Therefore, the development of alternative ways of producing large-scale HPV antigens has been essential to achieve an immunodiagnosis of HPV.

The detection of HPV DNA has been used as a marker for the presence of the virus in a cervical lesion, although this is not indicative of a productive infection or presence of a cervical lesion. Thus, clinical lesions and cytological alterations remain the most frequent methods used to identify precancerous lesions, some of which may be associated with the presence of HPV infection. However, nowadays clinicians are misusing Pap test and colposcopy to diagnose viral lesions. For this reason, molecular techniques have recently been introduced to detect HPV DNA in cervical samples that, in combination with Pap and colposcopy tests, aim to identify HPV infected women at risk of developing CC.

\section{Human papillomavirus}

HPV is part of the newly described papillomaviridae family. ${ }^{13}$ These viruses range in size between 55 and $60 \mathrm{~nm}$ and contain a capsid and a double strand DNA genome approximately $8000 \mathrm{bp}$ long. ${ }^{14}$ The viral genome contains open reading frames (ORFs) organized in three regions: the early expression region (E), the late region (L) and the long control region (LCR) that bears 
the origin of viral replication and transcription. ${ }^{15}$ The $\mathrm{E}$ region codes for proteins related to replication (E1) and to activation or repression of the viral DNA (E2). The E1 protein is an ATP hydrolyze and it is essential for HPV replication, ${ }^{16}$ while the E2 protein is a DNA binding protein able to trans-activate the HPV LCR region. ${ }^{17,18}$ The E2 ORF codes for at least two proteins that function as transcription factors and as internal regulators of the viral E6 and E7 oncogenes expression. ${ }^{15}$ The deletion of the E2 ORF is frequently observed in biopsies of cervical cancer and this suggests that the loss of the E2 gene expression allows for the over-expression of the E6 and E7 oncogenes which, in turn, initiates the transformation process. ${ }^{14} \mathrm{E} 4$ is another early expressing protein that binds to the cytoskeleton, to cytokeratins and to zinc, and these activities seem to be related to the collapse of the cytoskeleton, which enhances virus release. ${ }^{19,20}$

The mechanisms through which HPVs induce cell transformation have been intensively investigated during the last few years. The E6 and E7 open reading frames are the most abundant viral transcripts in tumors and tumor cell lines; these oncogenes are necessary and sufficient to induce an HPV-mediated transformation of murine cells ${ }^{21}$ and the immortalization of human fibroblasts. ${ }^{22}$ Moreover, the E7 gene corresponding to an HR type cooperates with ras in the transformation of baby rat kidney cells and primary human keratinocytes.22 The greatest evidence of the involvement of E6 and E7 in the process of malignant transformation comes from biochemical studies. E6 and E7 from HR-HPV types have the ability to alter pathways involved in cell cycle control by interacting with and neutralizing the regulatory function of suppressor proteins $\mathrm{p} 53$ and $\mathrm{pRb}$, respectively. ${ }^{23,24}$ More recently, it has been shown that HPV-16 E7 binds to other proteins that are important for the progression of the cell cycle, such as the $\mathrm{pRb}$-related protein $\mathrm{p} 107$ and the cyclin A/CDK2 complex that inhibits the interaction of $\mathrm{pRb}$ and the E2F promoter. All these studies suggest that the E7 protein plays a central role in the transformation process.

The E6 protein from HR-HPVs can induce the rapid degradation of p53 through an ubiquitin-dependent pathway, ${ }^{25}$ and it is able to interfere with the transcriptional function of p53 in vivo. ${ }^{26}$ Summarizing, it can be pointed out that oncogenic E6 and E7 proteins abolish the negative growth regulation process through the inhibition of proteins such as $\mathrm{p} 53$ and $\mathrm{pRb}$, resulting in genetic instability, and through the accumulation of mutations that might contribute to the final oncogenesis.

E5 is another oncogenic HPV protein able to induce the growth of murine cells in soft agar; this effect increases with the presence of EGF. ${ }^{27,28}$ It is also known that E5 increases the half-life of EGF and PDGF receptors in cells that have been transfected with it. ${ }^{27}$ Contrary to the behavior of $\mathrm{E} 6$ and $\mathrm{E} 7$, the $\mathrm{E} 5$ oncogene is lost in the late stages of CC due to the viral integration into the host genome; however, high levels of mRNA and protein are found in LSIL (low grade squamous intraepithelial lesion). ${ }^{29}$ Its close association with growth factor receptors could suggest that E5 plays a key role in the viral life cycle and that it may have an important function in the early development of the neoplasia, but it does not appear to be essential for the maintenance of the transformation stage.

Thus, it can be said that the development of cervical cancer is the consequence of an abortive viral cycle that generates the deregulation of the cell cycle at different levels, depending on the different HPV oncogenes (E5, E6 and E7), all of which allow the initiation of the malignant process.

\section{Molecular biology-based techniques}

There are several molecular techniques used for HPV DNA detection, most of which are used for research purposes. They include: a) DNA hybridization, ${ }^{30}$ b)PCR$\mathrm{RFLP}^{31,32} \mathrm{c}$ ) reverse-line hybridization ${ }^{33}$ and d) hybrid capture assay. ${ }^{34}$ The method most commonly used is the polymerase chain reaction (PCR). At present, several primers from different HPV genes have been designed, but the most popular ones are based on the L1 gene. Amplification of HPV DNA by L1 consensus primer systems (e.g., MY09/11 or GP5 ${ }^{+} / 6^{+}$) can detect as few as 10 to 100 molecules of HPV targets from a genital sample (Table I). ${ }^{35,36}$

\section{Detection of human papillomavirus infection by nucleic acid hybridization}

Single-stranded nucleic acid molecules that are complementary to each other will form hybrids under appropriate conditions. Hybridization tests are based on this phenomenon and they employ labeled probe molecules to detect specific complementary target molecules. Nucleic acid hybridization is the most sensitive method for detecting HPV in clinical specimens and the only one capable of identifying specific HPV types. There are many alternative hybridization test formats; most of them use either filters or glass slides as solid supports. Of the established tests, Southern blot hybridization remains the most sensitive and specific test for HPV DNA,${ }^{37}$ but has the drawback of also being the most time consuming. Several novel methods are promising and some innovative procedures may eventually dominate routine nucleic acid detection. The ideal test should be simple enough to allow automatization. 


\section{Table I}

\section{Comparison AMONG different TEST FOR HPV deteCtION}

\begin{tabular}{|c|c|c|c|c|c|}
\hline Test & Detects & Use & Sensitivity & Specificity & Lesion associated \\
\hline Papanicolaou & $\begin{array}{l}\text { Abnormal cells in } \\
\text { cervical scrapes }\end{array}$ & Possible cervical lesions & $50-84 \%$ & $91.25 \%$ & Possible cervical lesion \\
\hline Colposcopy & $\begin{array}{l}\text { Cervical neo- } \\
\text { plasia }\end{array}$ & Cervical lesions & $95 \%$ & $63.75 \%$ & Cervical lesion \\
\hline Virapap/ViraType ${ }^{37}$ & HPV DNA & Detection of $7 \mathrm{HPV}$ types & $79 \%$ & $79 \%$ & $\begin{array}{l}\text { Invasive Cancer } \\
\text { CIN } 3\end{array}$ \\
\hline PCR-restriction & HPV DNA & Detection and genotyping & $99.5 \%$ & $97.5 \%$ & Cervical cancer \\
\hline Hybrid capture $\mathrm{I}^{101,102}$ & HPV DNA & $\begin{array}{l}\text { Detection of high (9) or low-risk } \\
\text { mixed types (5) (separate assays) }\end{array}$ & $71.2 \%$ & $88.9 \%$ & HSIL \\
\hline Hybrid capture $I I^{101,102}$ & HPV DNA & $\begin{array}{l}\text { Detection of high (13) and/or low-risk } \\
\text { mixed types (5) (separate assays) }\end{array}$ & $\begin{array}{l}\text { I000 HPV DNA copies } \\
\text { or } 0.2-1 \text { pg HPV DNA } \\
>96 \%\end{array}$ & $66.7 \%$ & $\begin{array}{l}\text { Depends on viral load } \\
\text { HSIL } \\
(\text { CIN } 2 / 3+)\end{array}$ \\
\hline $\begin{array}{l}\text { INNO-LiPA detection/ } \\
\text { genotyping assay }{ }^{103}\end{array}$ & HPV DNA & $\begin{array}{l}\text { Detection and genotyping of } 25 \text { types } \\
\text { (high-and low-risk) and } \beta \text {-globin gene } \\
\text { detection (same assay). }\end{array}$ & $\begin{array}{l}98.4 \% \\
\text { mild-severe dyskaryo- } \\
\text { sis }\end{array}$ & $79.4 \%$ & $\begin{array}{l}\text { HPV prevalence increases } \\
\text { as the severity of the cervi- } \\
\text { cal lesion increases }\end{array}$ \\
\hline Reverse-line blot ${ }^{35}$ & HPV DNA & $\begin{array}{l}\text { Detection and genotyping of } 27 \text { types } \\
\text { (low and high-risk) and } \beta \text {-globin gene } \\
\text { detection (same assay) }\end{array}$ & 10-100 copies/ PCR & $\begin{array}{l}\text { Low cross- } \\
\text { reactivity be- } \\
\text { tween types }\end{array}$ & HPV prevalence \\
\hline AMPLICOR HPV test ${ }^{104}$ & HPV DNA & $\begin{array}{l}\text { Detection of } 13 \text { mixed high-risk } \\
\text { types and } \beta \text {-globin gene detection } \\
\text { (same assay). }\end{array}$ & $\begin{array}{l}100 \text { copies/ PCR of high } \\
\text { risk types } \\
95.2 \%\end{array}$ & $\begin{array}{l}\text { No cross- } \\
\text { reactivity } \\
\text { to low-risk } \\
\text { types } \\
96.7 \%\end{array}$ & $\begin{array}{l}\text { HPV prevalence increases } \\
\text { as the severity of the cervi- } \\
\text { cal lesion increases. } \\
\text { CIN2-3 } \\
\text { HSIL }\end{array}$ \\
\hline Linear Array HPV ${ }^{36}$ & HPV DNA & $\begin{array}{l}\text { Detection and genotyping of } 37 \text { ano- } \\
\text { genital types. }\end{array}$ & Still in trial & & Multiple infections \\
\hline COBAS TaqMan HPV & HPV DNA & High risk types and viral load & Still in trial & & Screening test \\
\hline ELISA-VLP-I6 & $\begin{array}{l}\text { Neutralizing anti- } \\
\text { bodies }\end{array}$ & HPV exposure & $53 \%$ & $97 \%$ & Cervical cancer \\
\hline ELISA-early proteins ${ }^{70,89}$ & $\begin{array}{l}\text { Antibodies to E4 } \\
\text { and E7 }\end{array}$ & $\begin{array}{l}\text { Serological markers of viral cycle and } \\
\text { lesion progression }\end{array}$ & $67 \%$ & $78 \%$ & $\begin{array}{l}\text { Anti-E4: LSIL } \\
\text { Anti-E7: Cervical cancer } \\
\text { and bad prognosis }\end{array}$ \\
\hline
\end{tabular}

Validation assays: correlation of filter in situ, dot blot and PCR with Southern blot

A number of validation experiments have compared the most commonly used HPV hybridization methods with the accepted gold standard -Southern blot hybridization. The methods discussed are filter in situ hybridization (FISH), dot blot hybridization (ViraPap/ ViraType), and polymerase chain reaction (PCR). FISH appears too inaccurate to be recommended for future epidemiological studies. ViraPap/ViraType agrees with Southern blot, but the sensitivity of the system is low as it only detects seven genital HPV types (Table I). ${ }^{37}$ PCR-based methods may be more sensitive than Southern blot and are likewise capable of detecting the most known genital HPV types. ${ }^{38}$ Direct comparison of the several available PCR methods has shown that they present different sensitivities and specificities, and this could be due to the use of different oligonucleotide probes directed to different HPV genes. The sensitivity of the PCR system could also be affected by the quality of the sample and the DNA extracted. Moreover, there is no standardized method for cervical sampling and sample medium preservation, which also accounts for the variability of the PCR systems. Currently, there is no perfect method for HPV testing because Southern blot itself is prone to some errors in performance and interpretation. Given that the scientific and clinical usefulness of HPV tests depends on the precision and accuracy of the assays, more intra- and inter-assay comparisons should be done to establish reference standards useful for this area of molecular diagnostics.

Genotyping HPV PCR products by a single-hybridization, reverse line blot

There are several molecular biology techniques used together as HPV detection methods. One is dot blot 
hybridization, where HPV type-specific oligonucleotide probes are immobilized on a solid phase and hybridized to a PCR product in the liquid phase. This procedure is complicated, especially when trying to detect separate HPV types, because it requires separate rounds of hybridization for each type detected. On the other hand, reverse hybridization systems provide an attractive tool for simultaneous hybridization of a PCR product to multiple oligonucleotide probes. The most frequently used methods involve a membrane strip containing multiple probes immobilized as parallel lines, called line probe (LiPA), line blot assay (LBA) or linear array (LA). 39,40 In this system, a PCR product is generated using biotinylated primers, denatured under alkaline conditions and added to the strip in a hybridization buffer. After hybridization and stringent washing, the hybrids can be detected by addition of a streptavidin-conjugate and a substrate generating color at the probe line, which can be visually interpreted. This method allows multiple HPV type detection in a single step and requires only a limited amount of PCR product. ${ }^{41-43}$

Alternative reverse hybridization methods for HPV and genotyping are the line blot assay using PGMY primers $^{35,44-47}$ and the reverse line blot for GP5 $+/ 6+{ }^{36}$ HPV DNA micro arrays work on the same principle. ${ }^{48,}$ ${ }^{49}$ Reverse hybridization methods are particularly useful for the detection of type-specific infections and multiple genotypes. Some reverse-line hybridization methods may include from 27 to 37 probes for different $H R$ and LR HPV types. The performance of the strip method has been evaluated relative to that of a previously reported dot blot format ${ }^{50}$ by testing 467 cervical swab samples collected in Digene specimen transport medium (Digene Diagnostics, Silver Spring, Md.). Using the PCR format, the researchers found that $46 \%$ of the study population was infected with HPV, whereas the ViraPap test showed an HPV prevalence of only $11 \%$. Nearly all of the discrepant HPV-positive samples resulted from weak signals and can be attributed to sampling error from specimens with low concentrations $(<1$ copy $/ \mu \mathrm{l})$ of HPV DNA. ${ }^{50}$ At the same time, the difference in sensitivity could be due to the low number of HPV types comprised in the different tests. The primary advantage of the strip-based detection system is the ability to rapidly genotype HPVs present in genital samples with high sensitivity and specificity, minimizing the likelihood of misclassification (Table I).

Detection of integrated HPV sequences by ligation-mediated PCR (DIPS-PCR)

The HPV genome usually persists as episomal molecules in HPV-associated preneoplastic lesions, where it is frequently integrated into the host cell genome in HPV-related cancer cells. This suggests that malignant conversion of HPV-infected epithelia is linked to the recombination of cellular and viral sequences. Due to technical limitations, precise sequence information on viral-cellular junctions was obtained only for a few cell lines and primary lesions. To facilitate the molecular analysis of genomic HPV integration, a ligation-mediated PCR assay was established for the detection of integrated HPV sequences (DIPS-PCR). This method was initially used to amplify genomic viral-cellular junctions from $\mathrm{HPV}$-associated cervical cancer cell lines (C4-I, C4-II, SW756 and HeLa) and HPV-immortalized keratinocyte lines (HPKIA, HPKII). In addition to junctions already reported, various new fusion fragments were identified. ${ }^{51}$ Different viral-cellular junctions were amplified from cervical carcinomas and a vulval intraepithelial neoplasia (VIN III). Sequence analysis of each junction revealed that the viral E1 ORF was fused to cellular sequences in $91 \%$ of the cases. Chromosomal integration loci mapped to chromosomes $1(2 n), 2$ (3n), $7(2 n), 8(3 n), 10$ (1n), $14(5 n), 16(1 n), 17$ (2n), and mitochondrial DNA (1n), suggesting random distribution of chromosomal integration sites. ${ }^{52}$ Precise sequence information obtained by DIPS-PCR is used to monitor the monoclonal origin of cervical cancers, recurrent pre-malignant lesions and lymph node metastasis. DIPS-PCR might be useful for efficient therapy control and prediction of relapse in patients with HPV-associated anogenital cancers.

\section{Immunological techniques}

The role played by the humoral immune response during the HPV infection is not very well understood; however, this response is generated all throughout the malignant process. This has allowed for the development of different techniques and reagents to detect antibodies against early and late HPV proteins. Among all these different techniques, recombinant fusion proteins have been used as antigens in Western blot, ${ }^{53-57}$ as synthetic peptides representing important immunogenic B-cell epitopes in the case of ELISA (Enzyme Linked Immunoabsorbent Assay), ${ }^{58,59}$ and modifications of this technique have been used to increase the specificity and sensitivity of the assay (Table I). Another system developed to detect HPV antibodies involves the in vitro protein transcription and translation used for radioimmunoprecipitation. ${ }^{60-63}$ All these techniques have shown that the measurement of antibodies against different HPV proteins could be useful biological markers of different types of lesions of the uterine cervix. 
Detection of antibodies against oncogenic HPV proteins by Western blot

The generation of recombinant HPV proteins through molecular biology techniques has allowed the isolation and purification of different viral antigens useful for detecting antibodies in different body samples (blood, saliva, cervical mucus). The Western blot assay is the most specific system used for the detection of antibodies, and it has been the confirmatory test for HIV and HSV infections. ${ }^{64,65}$ The advantage of Western blot assay is that a particular protein band, together with its molecular weight, can be detected from a mixture of antigens. However, due to the denaturing conditions that characterize this system, only linear epitopes are recognized and the complexity of the procedure makes it difficult to handle a large number of samples.

The Western blot technique involves the separation of the antigen by its molecular weight through a polyacrylamide gel electrophoresis followed by a transfer to nitrocellulose membranes. ${ }^{66}$ After the protein is transferred, the filters are blocked and cut into strips to be incubated with the patient sample (serum, saliva, cervical mucus) for 4-16 h. The antigen-antibody complex is detected by a secondary antibody complex conjugated with an oxidizing enzyme, such as horseradish peroxidase, producing a colored molecule or luminescence. Thus, a high correlation between the presence of HPV-16 E7 antibodies and CC was found by means of the Western blot system..$^{53,67-69}$ The presence of antiE4 antibodies has been controversial, as some groups found them equally distributed among healthy donors and cancer patients, ${ }^{53,57}$ while others reported that the prevalence of antibodies against HPV-16 E4 was higher in subjects with CC than in the control population. $55,68,70$ More recently, our group showed that anti-E4 antibodies can be used as markers for HPV infection as well as to detect early stages of cervical lesions (high antibody prevalence in CIN I-II lesions). ${ }^{71,72}$ In summary, the advantage of the Western blot system is the ability to detect antibodies against several linear epitopes, which accounts for its high specificity $(78 \%)$ and sensitivity $(67 \%)^{71}$ (Table I), and it is, hence, highly suitable for the diagnosis of different cervical lesions.

\section{HPV antibody detection by ELISA}

The ELISA is the main tool used for clinical diagnosis. It is mostly used to screen large populations and it has been widely used for molecular epidemiology research. The advantage of the ELISA is that both conformational and linear epitopes can be recognized by antibodies, as the method cannot be used under denaturing conditions.
The ELISA system has been broadly used to study the immunological response to different HPV antigens. In this sense, there are reports that show the presence of antibodies against the L1 capsid viral proteins in condyloma acuminata and in LSIL. ${ }^{73}$ These anti-L1 antibodies are scarce in HSIL (high grade squamous intraepithelial lesion) and are almost absent in CC. ${ }^{57}$ However, there are some controversies, as a high frequency of L1 antibodies has been reported in control populations. ${ }^{74}$ Further on, the development of Virus Like Particles (VLPs) allowed for a detection system that is more sensitive to anti-HPV antibodies and, hence, can identify conformational epitopes as well as neutralizing antibodies. ${ }^{75,76}$ The VLPs were initially produced from baculovirus and vaccinia virus, ${ }^{77,78}$ but more recently a recombinant yeast expression system driven by a strong galactose-inducible promoter was developed to express these antigens successfully. ${ }^{79}$ This material has been used for the development of the new HPV vaccine by Merk \& Co. ELISA assays for VLPs have been shown to be type-specific as low cross-reaction with HPVs from the same family has been found. A follow up study ${ }^{80}$ has shown that the detection of anti-VLPs antibodies by ELISA is useful to detect newly acquired HPV infections in virgin women. Another study showed that HPV-16 DNA-positive and anti-VLP-positive women had the highest risk of concurrent CIN 3 and cancer. ${ }^{81}$ An immunoglobulin type-specific ELISA-VLP system showed that the systemic IgA response was associated with successful clearance of HPV infection. At the same time, the presence of IgA anti-VLPs in HPV-16-positive women is very specific to detect actual infections that are in the process of being eliminated. ${ }^{82}$

In relation to the E2 protein, little has been done with this antigen. Dillner and coworkers ${ }^{58,83}$ used a peptide from the E2 protein C-terminal region to show that the $\operatorname{Ig} G$ and $\operatorname{Ig} A$ responses were elevated in patients with CC. Other reports show that the anti-E2 antibodies were present in normal subjects, ${ }^{84}$ they have also been shown to be markers of CIN lesions, but only in women over 40 years of age..$^{85}$

On the other hand, high concentrations of E4 ORF transcripts have been found in pre-cancerous lesions associated with HPV-16. Moreover, both LSIL and HSIL have been shown to exhibit the expression of the E4 protein, but not invasive cancer. ${ }^{86} \mathrm{E} 4$ antibodies have been found both in patients with pre-cancerous lesions and in normal subjects. ${ }^{53,63,83,86,87}$ Some groups report the presence of anti-E4 antibodies in cancer patients as well as in control groups, ${ }^{67,70}$ whereas others report a higher prevalence of E4 antibodies in cancer patients than in normal individuals. ${ }^{57,68,88}$ Previous studies in our laboratory have shown E4 antibodies to be highly 
associated with the CIN $1 / 2$ lesions. ${ }^{89}$ Due to the fact that $\mathrm{E} 4$ antibodies have been mainly found in early cervical lesions, it has been suggested that the E4 protein might be implicated in active viral replication. . $3,70^{2}$

There are several studies that have investigated the antibody response against E6 and E7 oncoproteins and it has been demonstrated that a higher proportion of antiE6 is present in patients with CC than in patients with early lesions or in healthy subjects..$^{57,60,90,91}$ In the case of HPV-16 E7 antibodies, a higher prevalence has been shown for CC patients compared to controls, 53,57,58,60,67$70,83,91-96$ suggesting that these antibodies might be used as markers for this type of cancer. Although the antibodies against these oncoproteins have enabled the identification of women with CC, this has occurred at a very late diagnostic stage. Thus, identifying biomarkers for early stages of CC will be essential in order to achieve an early diagnosis and offer timely treatment for women at risk of developing this disease. This also explains why studying the immune response against viral proteins (such as E2, E4 and E5 possibly related to the early stages in the development process of $\mathrm{CC}$ ) constitutes a very important research field.

It should also be noted that the use of different systems for the production of recombinant proteins, as well as the use of synthetic peptides, will allow the recognition of a greater number of epitopes on the viral proteins, and this will enhance the sensitivity of the immune assays. Recently, the identification of isotype profiles (IgG, IgA, IgM) against early HPV proteins (E4, E7) has shown to be useful to identify the infection stage important in the progression to CC. Moreover, combining diagnostic procedures (such as cytology, DNA and antibodies) will offer the possibility of a timely and accurate diagnosis, essential to detect women at high risk to develop CC. A detailed study of the humoral immune response against HPV antigens will allow the development of highly sensitive and specific diagnostic systems corresponding to the different HR-HPV types, as well as to follow up the protective immune response of the vaccinate population with the new HPV vaccine based on L1 antigens.

\section{Conclusions}

HPV cannot be grown in large quantities in cell culture. This fact has limited the use of common powerful immunological assays used for HPV diagnosis. Thus, the diagnosis of HPV-related diseases has relied on the detection of the viral DNA in patient samples. The use of molecular biology has enhanced a highly sensitive detection process of HPV DNA in the case of current infections, but this approach cannot determine whether the HPV infection is active, latent or persistent. On the other hand, these techniques are highly sensitive, but high technical skills are required for the sampling procedure. Large amounts of recombinant viral antigens as well as HPV-VLPs have been produced based on the most recent advances achieved by molecular biology. Thus, the humoral immune response offers the possibility to detect the infection stage as well as a follow-up process. However, a more specific antibody profile (immunoglobulin type) needs to be established to be able to discriminate between present and past infections.

Epidemiological studies have shown a wide range of HPV frequencies worldwide, ${ }^{50,97,98}$ but there is a high point prevalence of HPV among young women $(<30$ years).$^{99}$ Although nearly $90 \%$ of the HPV infections are cleared in less than 24 months, ${ }^{100}$ sampling errors and HPV-DNA detection techniques bearing different sensitivity and specificity appear to account for the heterogeneity of the results. To overcome these shortcomings, a combined detection system including HPV DNA detection (to identify the presence of the virus) and an antibody profile against different viral antigens (to determine the stage of the infection) will help to identify persistent infections that play an important role in the development of CC.

To close, it should be noted that the development of prophylactic HPV vaccines is a major advance in cancer prevention, as these vaccines protect against infection with certain oncogenic HPV types and, therefore, reduce the development of cervical lesions and the risk of CC. Routine HPV vaccination of adolescent girls will require screening guidelines in order to follow up the effectiveness of the vaccine protection. In this sense, immunological assays will not only be useful as specific biomarkers of the stage of the HPV infection and the lesions in women's cervixes, but they will also play an important role in the follow-up process of the protective immune response against $H P V$ in vaccinated populations.

\section{References}

I. Eluf-Neto J, Nascimento CM. Cervical cancer in Latin America. Semin Oncol 200I;28(2): I88-197.

2. World Health Organization. [Accessed August 7, 2003]. Available at: http://www.who.int/en/.

3. Blumenthal PD, Ringers P, McIntosh N, Graffikin L. Innovative approaches to cervical cancer prevention. Medscape Womens Health $2001 ; 6: 1$.

4. McCracken M, Olsen M, Chen MS Jr, Jemal A, Thun M, Cokkinides V, et al. Cancer incidence, mortality, and associated risk factors among Asian Americans of Chinese, Filipino,Vietnamese, Korean, and Japanese ethnicities. CA Cancer J Clin 2007;57(4): 190-205. 
5. Tapia-Conyer R, Kuri-Morales P, Macías-Martínez CG. Registro Histopatológico de Neoplasias en México. Mexico: Dirección General de Epidemiología, Secretaría de Salud, 2000.

6. Flores Y, Keerti S, Lazcano-Ponce E, Hernandez M, Bishai D, Ferris DG et al. Design and methods of the evaluation of an HPV-based cervical cancer screening strategy in Mexico:The Morelos HPV Study. Salud Publica Mex 2002:44:335-344.

7. Lazcano-Ponce E,Alonso P, Ruiz-Moreno JA, Hernández-Avila M. Recommendations for cervical cancer screening programs in developing countries. The need for equity and technological development. Salud Publica Mex 2003;45 suppl 3:S449-S462.

8. Walboomers JM, Jacobs MV, Manos MM, Bosch FX, Kummer JA, Shah $\mathrm{KV}$, et al. Human papillomavirus is a necessary cause of invasive cervical cancer worldwide. J. Patol 1999; I89:12-19.

9. Bosch FX, Lorincz A, Muñoz N, Meijer CJ, Shah KV.The causal relation between human papillomavirus and cervical cancer.J Clin Pathol 2002;55:244-265.

10. Muñoz N, Bosch FX, de Sanjosé S, Herrero R, Castellsagué X, Shah KV, et al. Epidemiologic classification of human papillomavirus types associated with cervical cancer. N Engl J Med 2003;348:5 18-527.

II. Dillner J.The serological response to papillomaviruses. Semin Cancer Biol 1999;9(6):423-430.

12. Chow LT, Broker TR. In vitro experimental systems for HPV: epithelial raft cultures for investigations of viral reproduction and pathogenesis and for genetic analyses of viral proteins and regulatory sequences. Clin Dermatol 1997;15(2):217-227.

13. de Villiers EM, Fauquet C, Broker TR, Bernard HU, zur Hausen $\mathrm{H}$. Classification of Papillomaviruses.Virol 2004;324: 17-27.

14. zur Hausen H. Papillomaviruses in human cancers. In: Infectious causes of cancer:Targets for intervention. Ed. Goedert J]. USA:Humana Press, 2000:245-261

15. zur Hausen H. Roots and perspectives of contemporary papillomavirus research.J. Cancer Res Clin Oncol 1996;122:3-13.

16. Beutner KR, Tyring S. Human papillomavirus and human disease.Am J Med 1997;102(5A):9-15.

17. García-Carrancá A, Gariglio PV. Molecular aspects of human papillomaviruses and their relation to uterine cervix cancer. Rev Invest Clin 1993;45(I):85-92.

18. Hebner CM, Laimins LA. Human papillomaviruses: basic mechanisms of pathogenesis and oncogenicity. Rev Med Virol 2006;16(2):83-97.

19. Gaillard-R C, Breitburd F, Orth G. Human Papillomavirus type I

E4 N-terminal ends has distinct cellular localizations when transiently expressed in vitro. JVirol 1992;66:816-823.

20. Roberts S, Ashmole I, Gibson LJ, Rookes SM, Barton GJ, Gallimore PH. Mutational analysis of Human Papillomavirus E4 proteins: Identification of structural features important in the formation of cytoplasmic E4/ cytokeratin networks in epithelial cells. JVirol 1994;68:6432-6445.

21.Yasumoto S, Burkhardt AL, Doniger J, DiPaolo JA. Human papillomavirus type 16 DNA-induced malignant transformation of $\mathrm{NIH}$ 3T3 cells. JVirol 1986;57:572-577.

22. Pirisi L, Yasumoto S, Feller M, Doniger J, DiPaolo JA. Transformation of human fibroblasts and keratinocytes with human papillomavirus type 16 DNA.JVirol 1987;61:1061-1066.

23. Dyson N, Guida P, Munger K, Harlow E. Homologous sequences in adenovirus EIA and human papillomavirus E7 proteins mediate interaction with the same set of cellular proteins. JVirol 1992;66:6893-6902.

24. Werness BA, Levine AJ. Howley PM,Association of human papillomavirus types 16 and $18 \mathrm{E} 6$ proteins with $\mathrm{p} 53$. Science 1990;248:76-79.

25. Scheffner M,Werness BA, Huibregtse JM, Levine AJ, Howley PM. The E6 oncoprotein encoded by human papillomavirus types 16 and 18 promotes the degradation of p53. Cell I990 63:I I29-II36.
26. Mietz JA, Unger T, Huibregtse JM, Howley PM. The transcriptional transactivation function of wild-type $p 53$ is inhibited by SV 40 large T-antigen and by HPV-16 E6 oncoprotein. EMBO J 1992; I ( I3):50 I3-5020. 27. Leechanachai P, Banks L, Moreau F, Matlashewski G. The E5 gene from human papillomavirus type 16 is an oncogene which enhances growth factor-mediated signal transduction to the nucleus. Oncogene 1992;7(I):19-25.

28. BouvardV, Matlashewski G, Gu Z-M, Storey A, Banks L. The human papillomavirus type 16 E5 gene cooperates with the E7 gene to stimulate proliferation of primary cells and increases viral gene expression.Virology 1994;203:73-80.

29. Biswas C, Kell B, Mant C, Jewers RJ, Cason J, Muir P, et al. Detection of human papillomavirus type 16 early-gene transcription by reverse transcription-PCR is associated with abnormal cervical cytology.J Clin Microbiol 1997;35(6): 1560-I564.

30. Denny LA,Wright TC Jr. Human papillomavirus testing and screening. Best Pract Res Clin Obstet Gynaecol 2005;19:50I-515.

3I. Brink AA, Snijders PJ, Meijer CJ. HPV detection methods. Dis Markers 2007; 23: 273-28I.

32. Molijn A, Kleter B, Quint W, van Doorn LJ. Molecular diagnosis of human papillomavirus (HPV) infections.J Clin Virol 2005;32 suppl I:S43-S5I.

33. Klug SJ, Molijn A, Schopp B, Holz B, Iftner A, Quint W, et al. Comparison of the performance of different HPV genotyping methods for detecting genital HPV types. J Med Virol 2008;80:1264-1274.

34. Lörincz AT. Screening for cervical cancer: new alternatives and research. Salud Publica Mex 2003;45 suppl 3:S376-S387.

35. Gravitt PE, Peyton CN,Apple RJ,Wheeler CM. Genotyping of 27 Human Papillomavirus Types by Using LI Consensus PCR Products by a Single-Hybridization, Reverse Line Blot Detection Method.J Clin Microbiol 1998;36(I0):3020-3027.

36. van den Brule AJ, Pol R, Fransen-Daalmeijer N, Schouls LM, Meijer C], Snijders PJ. GP5+/6+ PCR followed by reverse line blot analysis enables rapid and high-throughput identification of human papillomavirus genotypes. J Clin Microbiol 2002;40(3):779-787.

37. Schiffman MH.Validation of hybridization assays: correlation of filter in situ, dot blot and PCR with Southern blot. IARC Sci Publ 1992; I 19:169-179. 38. Nijhuis ER, Reesink-Peters N,Wisman GB, Nijman HW, van Zanden J, Volders $\mathrm{H}$, et al. An overview of innovative techniques to improve cervical cancer screening. Cell Oncol 2006;28(5-6):233-246.

39. Castle PE, Gravitt PE, Solomon D, Wheeler CM, Schiffman M.

Comparison of linear array and line blot assay for detection of human papillomavirus and diagnosis of cervical precancer and cancer in the atypical squamous cell of undetermined significance and lowgrade squamous intraepithelial lesion triage study.J Clin Microbiol 2008;46(I):109-117.

40. Sabol I, Salakova M, Smahelova J, Pawlita M, Schmitt M, Gasperov NM, et al. Evaluation of different techniques for identification of human papillomavirus types of low prevalence.J Clin Microbiol 2008;46(5):1606-1613.

4I. Kleter B, van Doorn LJ, Schrauwen L, Molijn A, Sastrowijoto S, ter Schegget J, et al. Development and clinical evaluation of a highly sensitive PCR-reverse hybridization line probe assay for detection and identification of anogenital human papillomavirus. J Clin Microbiol 1999;37(8):2508-25I7.

42. Melchers WJ, Bakkers JM,Wang J, de Wilde PC, Boonstra H, Quint WG, et al. Short fragment polymerase chain reaction reverse hybridization line probe assay to detect and genotype a broad spectrum of human papillomavirus types. Clinical evaluation and follow-up. Am J Pathol 1999;155(5): | 473-1478.

43. Quint WG, Scholte G, van Doorn LJ, Kleter B, Smits PH, Lindeman J. Comparative analysis of human papillomavirus infections in cervical scrapes and biopsy specimens by general SPF (10) PCR and HPV genotyping.J Pathol 200I;194:5I-58. 
44. Coutlée F, Gravitt P, Richardson H, Hankins C, Franco E, Lapointe N, et al. Nonisotopic detection and typing of human papillomavirus DNA in genital samples by the line blot assay. The Canadian Women's HIV study group.J Clin Microbiol 1999;37(6): I852-1857.

45.Vernon SD, Unger ER, Williams D. Comparison of human papillomavirus detection and typing by cycle sequencing, line blotting, and hybrid capture.J Clin Microbiol 2000;38(2):65I-655.

46. Gravitt PE, Peyton CL,Alessi TQ, Wheeler CM, Coutlée F, Hildesheim $\mathrm{A}$, et al. Improved amplification of genital human papillomaviruses. J Clin Microbiol 2000;38(I):357-36I.

47. Lazcano-Ponce E, Herrero R, Muñoz N, Cruz A, Shah KV,Alonso P, et al. Epidemiology of HPV infection among Mexican women with normal cervical cytology. Int J Cancer 200I;9I(3):4I 2-420.

48. Klaassen CH, Prinsen CF, de Valk HA, Horrevorts AM, Jeunink MA, Thunnissen FB. DNA microarray format for detection and subtyping of human papillomavirus. J Clin Microbiol 2004;42(5):2152-2160.

49. Park TW, Zivanovic O, Theuerkauf I, Dürkop B, Hernando JJ, Simon M, et al. The diagnostic utility of human papillomavirus-testing in combination with immunohistochemistry in advanced gynaecologic pelvic tumours: a new diagnostic approach. Int J Oncol 2004;24(4):829-836.

50. Bauer HM, Ting Y, Greer CE, Chambers JC, Tashiro CJ, Chimera J, et al. Genital human papillomavirus infection in female university students as determined by a PCR-based method. JAMA 1991;265(4):472-477. 5I. Luft F, Klaes R, Nees M, Dürst M, Heilmann V, Melsheimer P, et al. Detection of integrated papillomavirus sequences by ligation-mediated PCR (DIPS-PCR) and molecular characterization in cervical cancer cells. Int J Cancer 200I;92(I):9-17.

52. De Marco L, Gillio-Tos A, Bonello L, Ghisetti V, Ronco G, Merletti F. Detection of human papillomavirus type 16 integration in pre-neoplastic cervical lesions and confirmation by DIPS-PCR and sequencing. J Clin Virol 2007;38(I):7-13.

53. Jochmus-Kudielka I, Schneider A, Braun R, Kimming R, Koldovsky U, Schneweis KE, et al.Antibodies against the human papillomavirus type 16 early proteins in human sera: correlation of anti-E7 reactivity with cervical cancer.J Natl Cancer Inst 1989;81:1698-1704

54. Jenison SA, Yu XP, Valentine JM, Koutsky LA, Christiansen AE, Beckmann AM, et al. Evidence of prevalent genital-type human papillomavirus infections in adults and children.J Infect Dis 1990;162(I):60-69.

55. Köchel HG, Sievert K, Monazahian M, Mittlestäd-Deterding A, Teichmann A, Thomssen R.Antibodies to human papillomavirus type- 16 in human sera as reveled by the use of prokaryotically expressed viral gene products.Virology 1991;182:644-654.

56. Mandelson MT, Jenison SA, Sherman KJ,Valentine JM, McKnight B, Daling $J R$, et al.The association of human papillomavirus antibodies with cervical cancer risk. Cancer Epidemiol Biomarkers Prev 1992; I (4):28I-286. 57. Ghosh AK, Smith NK, Stacey SN, Glew SS, Connor ME,Arrand JR, et al. Serological responses to HPVI6 in cervical dysplasia and neoplasia: correlation of antibodies to E6 with cervical cancer. Int J Cancer 1993;53:59|-596.

58. Dillner J. Mapping of linear epitopes of human papillomavirus type 16: the EI, E2, E4, E5, E6 and E7 open reading frames. Int J Cancer 1990;46(4):703-7II.

59. Müller M, Gausepohl H, de Martynoff G, Frank R, Brasseur R, Gissmann L. Identification of seroreactive regions of the human papillomavirus type 16 protein E4, E6, E7 and LI.J Gen Virol 1990;7I (Pt II):2709-27I7.

60. Viscidi RP, Sun Y,Tsuzaki B, Bosch FX, Muñoz N, Shah KV. Serologic response in human papillomavirus-associated invasive cervical cancer. Int J Cancer 1993;55(5):780-784.

61. Nindl I, Benitez-Bribiesca L, Berumen J, Farmanara N, Fisher S, Gross $\mathrm{G}$, et al. Antibodies against linear and conformational epitopes of the human papillomavirus (HPV) type $16 \mathrm{E6}$ and $\mathrm{E7}$ oncoproteins in sera of cervical cancer patients. Arch Virol 1994;137(3-4):341-353.
62. Sun Y, Shah KV, Müller M, Muñoz N, Bosch XF,Viscidi RP.

Comparison of peptide enzyme-linked immunosorbent assay and radioimmunoprecipitation assay with in vitro-translated proteins for detection of serum antibodies to human papillomavirus type 16 E6 and E7 proteins. J Clin Microbiol 1994;32(9):2216-2220.

63. Müller M,Viscidi RP, Ulken V, Bavinck JN, Hill PM, Fisher SG, et al. Antibodies to the E4, E6, and E7 proteins of human papillomavirus (HPV) type 16 in patients with HPV-associated diseases and in the normal population.J Invest Dermatol 1995; 104(I):138-141.

64. Dax, EM,Arnott A. Advances in laboratory testing for HIV. Pathology 2004;36:55I-560.

65. Constantine, NT, Zink H. HIV testing technologies after two decades of evolution. Indian J Med Res 2005; 121:519-538.

66. Towbin H, Staehelin T, Gordon J. Electrophoretic transfer of proteins from polyacrylamide gels to nitrocellulose sheets: Procedure and some applications. Proc Natl Acad Sci 1979;76:4350-4354.

67. Köchel HG, Monazahian M, Sievert K, Hohne M, Thomssen C, Teichmann A, et al. Occurrence of antibodies of LI, L2, E4 and E7 gene products of human papillomavirus types $6 \mathrm{~b}, 16$ and 18 among cervicalcancer patients and controls. Int J Cancer 199|;48:682-688.

68. Suchánková A, Ritterová L, Krcmár M, Krchnák V,Vágner J, Jochmus I, et al. Comparison of ELISA and Western blotting for human papillomavirus type I6 E7 antibody determination.J Gen Virol 1991;72:2577-258I. 69. Fujii T, Matsushima Y,Yajima M, Sugimura T, Terada M. Serum antibody against unfused recombinant $E 7$ protein of human papillomavirus type 16 in cervical cancer patients. Jpn J Cancer Res 1995;86:28-34.

70. Kanda T, Onda T, Zanma S, Yasugi T, Furuno A, Watanabe S, et al. Independent association of antibodies against HPV type I6 EI/E4 and E7 proteins with cervical cancer.Virol 1992;190:724-732.

7I. Pedroza-Saavedra A, Cruz A, Esquivel F, De La Torre F, Berumen J, Gariglio P, et al. High prevalence of serum antibodies to Ras and type 16 E4 proteins of human papillomavirus in patients with precancerous lesions of the uterine cervix. Arch Virol 2000; 145(3):603-623.

72. Middleton K, Peh V, Southern S, Griffin H, Stolar K, Nakahara T, et al. Organization of human papillomavirus productive cycle during neoplastic progression provides a basis for selection of diagnostic markers. JVirol 2003;77(19): I0186-10201.

73. Jenison SA, Yu XP,Valentine JM, Galloway DA. Human antibodies react with an epitope of the human papillomavirus type $6 \mathrm{~b} \mathrm{LI}$ open reading frame which is distinct from the type-common epitope. JVirol 1989;63(2):809-818.

74. Di Lonardo A, Campo MS, Venuti A, Marcante ML. Brief report: antibody response to $E 6, E 7$, and $L I$ proteins of human papillomavirus $I 6$ in an Italian population.J Med Virol 1994;43(4):357-36I.

75. Zhou J, Sun XY, Davies H, Crawford L, Park D, Frazer IH. Definition of linear antigenic regions of the HPVI6 LI capsid protein using synthetic virion-like particles.Virology 1992;189(2):592-599.

76. Xu YF, Zhang YQ, Xu XM, Song GX. Papillomavirus virus-like particles as vehicles for the delivery of epitopes or genes. Arch Virol 2006; I5I(II):2133-2I 48.

77. Zhou J, Sun XY, Stenzel DJ, Frazer IH. Expression of vaccinia recombinant HPV I6 LI and L2 ORF proteins in epithelial cells is sufficient for assembly of HPV virion-like particles. Virology 199|;|85(I):25I-257.

78. Kirnbauer R, Hubbert NL, Wheeler CM, Becker TM, Lowy DR, Schiller JT.A virus-like particle enzyme-linked immunosorbent assay detects serum antibodies in a majority of women infected with human papillomavirus type 16.J Natl Cancer Inst 1994;86(7):494-499.

79. Hofmann KJ, Neeper MP, Markus HZ, Brown DR, Müller M, Jansen $\mathrm{KU}$. Sequence conservation within the major capsid protein of human papillomavirus (HPV) type 18 and formation of HPV-18 virus-like particles in Saccharomyces cerevisiae. J Gen Virol 1996;77(Pt 3):465-468. 
80. Kjaer SK, Chackerian B, van den Brule AJ, Svare El, Paull G, Walbomers JM, et al. High-risk human papillomavirus is sexually transmitted: evidence from a follow-up study of virgins starting sexual activity (intercourse). Cancer Epidemiol Biomarkers Prev 2001;10(2):101-106.

8I. Wang SS, Schiffman M, Shields TS, Herrero R, Hildesheim A, Bratti MC, et al. Seroprevalence of human papillomavirus- $16,-18,-3 \mid$, and -45 in a population-based cohort of 10000 women in Costa Rica. Br J Cancer 2003;89(7): I248-1254.

82. Bontkes HJ, de Gruijl TD, Walboomers JM, Schiller JT, Dillner J, Helmerhorst TJ, et al. Immune responses against human papillomavirus (HPV) type 16 virus-like particles in a cohort study of women with cervical intraepithelial neoplasia. II. Systemic but not local IgA responses correlate with clearance of HPV-16.J Gen Virol 1999;80 (Pt 2):409-417. 83. Dillner J, Lenner P, Lehtinen M, Eklund C, Heino P,Wiklund F, et al.A population-based seroepidemiological study of cervical cancer. Cancer Res. 1994;54(I):|34-|4|.

84.Veress G, Kónya J, Csiky-Mészáros T, Czeglédy J, Gergely L. Human papillomavirus DNA and anti-HPV secretory lgA antibodies in cytologically normal cervical specimens. J MedVirol 1994;43(2):20I-207. 85. Marais D, Rose RC,Williamson AL.Age distribution of antibodies to human papillomavirus in children, women with cervical intraepithelial neoplasia and blood donors from South Africa.J Med Virol 1997;5I(2):|26-|3|.

86. Crum CP, Barber S, Symbula M, Snyder K, Saleh AM, Roche JK. Coexpression of the human papillomavirus type $16 \mathrm{E} 4$ and LI open reading frames in early cervical neoplasia.Virology 1990; I78(I):238-246. 87. Snyder KA, Barber SR, Symbula M, Taylor PT, Crum CP, Roche JK. Binding by immunoglobulin to the HPV-16-derived proteins LI and E4 in cervical secretions of women with HPV-related cervical disease. Cancer Res 1991;5I(I6):4423-4429.

88. Gaarenstroom KN, Kenter GG, Bonfrer JM, Korse CM, Gallee MP, Hart AA, et al. Prognostic significance of serum antibodies to human papillomavirus-16 E4 and E7 peptides in cervical cancer. Cancer 1994;74(8):2307-23।3.

89. Vazquez-Corzo S, Trejo-Becerril C, Cruz-Valdez A, Hernandez-Nevarez P, Esquivel-Guadarrama R, Gutierrez-Xicotencatl L. Association between anti-Ras and anti-HPVI6 E4/E7 with intraepihelial cervical lesions. Rev Salud Pub Mex 2003;45:335-345. Available at: http://www.insp.mx/ salud/45/eng/i455_I.pdf.

90. Bleul C, Müller M, Frank R, Gausepohl H, Koldovsky U, Mgaya HN, et al. Human papillomavirus type $18 \mathrm{E} 6$ and $\mathrm{E} 7$ antibodies in human sera: increased anti-E7 prevalence in cervical cancer patients. J Clin Microbiol |99|;29(8):| 1579-|588
91. Müller M,Viscidi RP, Sun Y, Guerrero E, Hill PM, Shah F, et al.Antibodies to HPV-16 E6 and E7 proteins as markers for HPV-16-associated invasive cervical cancer.Virology 1992; 187(2):508-5/4.

92. Krchnák V,Vágner J, Suchánková A, Krcmár M, Ritterová L,Vonka V. Synthetic peptides derived from E7 region of human papillomavirus type 16 used as antigens in ELISA.J Gen Virol 1990;7 ( (Pt II):2719-2724. 93. Dillner J. Disappearance of antibodies to HPV 16 E7 after treatment for cervical cancer. Lancet 1993;34I(8860):I594.

94. Hamsiková E, Novák J, Hofmannová V, Munoz N, Bosch FX, de Sanjosé S. Presence of antibodies to seven human papillomavirus type 16-derived peptides in cervical cancer patients and healthy controls.J Infect Dis 1994; |70(6): |424- |43|.

95. de Sanjosé S, Bosch FX, Muñoz N, Tafur L, Gili M, Izarzugaza I, et al. Socioeconomic differences in cervical cancer: two case-control studies in Colombia and Spain. Am J Public Health 1996;86(I I): I532-I538. 96. Fisher SG, Benitez-Bribiesca L, Nindl I, Stockfleth E, Muller M, Wolf $\mathrm{H}$, et al. The association of human papillomavirus type $16 \mathrm{E} 6$ and E7 antibodies with stage of cervical cancer. Gynecol Oncol 1996;6I(I):73-78. 97. Yamada T, Manos MM, Peto J, Greer CE, Munoz N, Bosch FX, et al. Human papillomavirus type 16 sequence variation in cervical cancers: a worldwide perspective. JVirol 1997;7I(3):2463-2472

98. Muñoz N. Human papillomavirus and cancer: the epidemiological evidence.J Clin Virol 2000; I (1-2):I-5.

99. de Roda-Husman AM, Walboomers JM, Hopman E, Bleker OP, Helmerhorst TM, Rozendaal L, et al. HPV prevalence in cytomorphologically normal cervical scrapes of pregnant women as determined by PCR: the age-related pattern.J Med Virol 1995;46(2):97-102. 100. Moscicki AB. HPV infections in adolescents. Dis Markers 2007; 23(4): 229-234.

I0I. Poljak M, Brencic A, Seme K,Vince A, Marin IJ. Comparative evaluation of first- and second-generation digene hybrid capture assays for detection of human papillomaviruses associated with high or intermediate risk for cervical cancer.J Clin Microbiol 1999;37(3):796-797.

102. Clavel C, Masure M, Putaud I,Thomas K, Bory JP, Gabriel R, et al. Hybrid capture II, a new sensitive test for human papillomavirus detection. Comparison with hybrid capture I and PCR results in cervical lesions. J Clin Pathol 1998;5I(I0):737-740.

103. Monsonego J, Bohbot JM, Pollini G, Krawec C,Vincent C, Merignargues I, et al. Performance of the Roche AMPLICOR human papillomavirus (HPV) test in prediction of cervical intraepithelial neoplasia $(\mathrm{CIN})$ in women with abnormal PAP smear. Gynecol Oncol 2005;99(I):160-I68. 